Check for updates

Cite this: RSC Adv., 2019, 9, 27334

Received 8th July 2019

Accepted 17th August 2019

DOI: $10.1039 / c 9 r a 05193 g$

rsc.li/rsc-advances

\section{A theoretical study on the formation and oxidation mechanism of hydroxyalkylsulfonate in the atmospheric aqueous phase}

\begin{abstract}
Danna Zhang, (DD ${ }^{a}$ Guochun Lv, ${ }^{a}$ Xiaomin Sun, ${ }^{\star a}$ Chenxi Zhang ${ }^{\text {DD }}{ }^{\mathrm{b}}$ and Zhiqiang Li ${ }^{\star c}$
Hydroxymethanesulfonate (HMS) is an important organosulfur compound in the atmosphere. In this work, we studied the formation mechanism of $\mathrm{HMS}$ via the reaction of formaldehyde with dissolved $\mathrm{SO}_{2}$ using the quantum chemistry calculations. The results show that the barrier $\left(9.7 \mathrm{kcal} \mathrm{mol}^{-1}\right)$ of the $\mathrm{HCHO}+\mathrm{HSO}_{3}{ }^{-}$ reaction is higher than that $\left(1.6 \mathrm{kcal} \mathrm{mol}^{-1}\right)$ of the $\mathrm{HCHO}+\mathrm{SO}_{3}{ }^{2-}$ reaction, indicating that the $\mathrm{HCHO}+$ $\mathrm{SO}_{3}{ }^{2-}$ reaction is easier to occur. For comparison, the reaction of acetaldehyde with dissolved $\mathrm{SO}_{2}$ also was discussed. The barriers for the $\mathrm{CH}_{3} \mathrm{CHO}+\mathrm{HSO}_{3}{ }^{-}$reaction and $\mathrm{CH}_{3} \mathrm{CHO}+\mathrm{SO}_{3}{ }^{2-}$ reaction are $16.6 \mathrm{kcal} \mathrm{mol}^{-1}, 2.5 \mathrm{kcal} \mathrm{mol}^{-1}$, respectively. This result suggests that the reactivity of $\mathrm{HCHO}$ with dissolved $\mathrm{SO}_{2}$ is higher than that of $\mathrm{CH}_{3} \mathrm{CHO}$. The further oxidation of $\mathrm{CH}_{2}(\mathrm{OH}) \mathrm{SO}_{3}{ }^{-}$and $\mathrm{CH}_{3} \mathrm{CH}(\mathrm{OH})$ $\mathrm{SO}_{3}{ }^{-}$by an $\mathrm{OH}$ radical and $\mathrm{O}_{2}$ shows that the $\mathrm{SO}_{5}{ }^{\cdot-}$ radical can be produced.
\end{abstract}

\section{Introduction}

Organosulfur compounds (OS), including organosulfates $\left(\mathrm{ROSO}_{3}{ }^{-}\right)$, sulfones $\left(\mathrm{RSO}_{2} \mathrm{R}^{\prime}\right)$, and sulfonates $\left(\mathrm{RSO}_{3}{ }^{-}\right),{ }^{1,2}$ have been identified to widely exist in fog, rainwater and in ambient atmosphere aerosols. ${ }^{3-6}$ These OS can be produced from marine sources including dimethylsulfide (DMS) emissions and oxidation of primary marine biomass, $, 7,8$ and their formation can be affected by aerosol acidity, relative humidity and concentration of nitrogen oxides $\left(\mathrm{NO}_{x}\right)^{3,9,10}$ Hydroxymethanesulfonate (HMS) is one of the important organosulfur compounds and is a significant contributor to secondary aerosol formation. ${ }^{6}$ The other hydroxyalkylsulfonate species are considered to be less important than HMS. ${ }^{11}$ HMS has been misidentified as inorganic sulfate $\left(\mathrm{SO}_{4}{ }^{2-}\right)$ for a long time, which results in discrepancies between sulfate observation and model results. As a matter of fact, HMS is an important OS compound, and it may account for about $1 / 3$ of the missing sulfate in Beijing winter haze aerosols. ${ }^{12}$

The formation of HMS has been studied by many researchers. The reaction between $\mathrm{SO}_{2}$ and $\mathrm{HCHO}$ contributes to its formation. Wagner et al. proposed that the reaction rate was determined by both $\mathrm{HSO}_{3}{ }^{-}$and $\mathrm{SO}_{3}{ }^{2-}\left(\mathrm{HCHO}+\mathrm{HSO}_{3}{ }^{-} \rightarrow\right.$ $\mathrm{CH}_{2}(\mathrm{OH}) \mathrm{SO}_{3}{ }^{-} ; \mathrm{H}_{2} \mathrm{O}+\mathrm{HCHO}+\mathrm{SO}_{3}{ }^{2-} \rightarrow \mathrm{CH}_{2}(\mathrm{OH}) \mathrm{SO}_{3}{ }^{-}+$ $\left.\mathrm{OH}^{-}\right) .{ }^{13}$ But in subsequent study, Peter et al. disagreed with Wagner's conclusion and thought that termolecular process

${ }^{a}$ Environment Research Institute, Shandong University, Jinan 250100, China. E-mail: sxmwch@sdu.edu.cn

${ }^{b}$ College of Biological and Environmental Engineering, Binzhou University, Binzhou 256600, China

${ }^{c}$ Center for Optics Research and Engineering (CORE), Shandong University, Qingdao 266237, China. E-mail: lzq@sdu.edu.cn
$\left(\mathrm{H}_{2} \mathrm{O}+\mathrm{HCHO}+\mathrm{SO}_{3}{ }^{2-} \rightarrow \mathrm{CH}_{2}(\mathrm{OH}) \mathrm{SO}_{3}{ }^{-}+\mathrm{OH}^{-}\right)$was impossible, and the kinetics should be explained by such reactions: $\mathrm{HCHO}+$ $\mathrm{HSO}_{3}{ }^{-} \rightarrow \mathrm{CH}_{2}(\mathrm{OH}) \mathrm{SO}_{3}{ }^{-} ; \mathrm{HSO}_{3}{ }^{-} \leftrightarrow \mathrm{SO}_{3}{ }^{2-}+\mathrm{H}^{+}$. They believed that only $\mathrm{HSO}_{3}{ }^{-}$could react with $\mathrm{HCHO}$ and determine the reaction rate. ${ }^{14}$ However, the experiment using spectrophotometer showed that the $\mathrm{SO}_{3}{ }^{2-}$ reacts rapidly with $\mathrm{HCHO} .{ }^{15} \mathrm{In}$ the spectrophotometric study on the reaction between dissolved $\mathrm{SO}_{2}$ and $\mathrm{HCHO}$, it can be concluded that $\mathrm{HSO}_{3}{ }^{-}$and $\mathrm{SO}_{3}{ }^{2-}$ can react with $\mathrm{HCHO}$, and the rate for $\mathrm{SO}_{3}{ }^{2-}$ is higher than $\mathrm{HSO}_{3}{ }^{-}$ obviously. ${ }^{16}$ In a recent research, the important organosulfur compound (HMS) was been investigated for its important role in haze aerosols. ${ }^{12}$ And this paper proposed a potentially HMS chemical mechanism. According to the analysis above, the chemical formation of HMS can be illustrated as: $:^{16,17}$

$$
\begin{gathered}
\mathrm{SO}_{2} \cdot \mathrm{H}_{2} \mathrm{O} \leftrightarrow \mathrm{HSO}_{3}^{-}+\mathrm{H}^{+} \\
\mathrm{HSO}_{3}{ }^{-} \leftrightarrow \mathrm{SO}_{3}{ }^{2-}+\mathrm{H}^{+} \\
\mathrm{HCHO}+\mathrm{HSO}_{3}{ }^{-} \leftrightarrow \mathrm{CH}_{2}(\mathrm{OH}) \mathrm{SO}_{3}{ }^{-} \\
\mathrm{HCHO}+\mathrm{SO}_{3}{ }^{2-} \leftrightarrow \mathrm{CH}_{2}\left(\mathrm{O}^{-}\right) \mathrm{SO}_{3}{ }^{-} \\
\mathrm{CH}_{2}(\mathrm{OH}) \mathrm{SO}_{3}{ }^{-} \leftrightarrow \mathrm{CH}_{2}\left(\mathrm{O}^{-}\right) \mathrm{SO}_{3}{ }^{-}+\mathrm{H}^{+} \\
\mathrm{CH}_{2}(\mathrm{OH}) \mathrm{SO}_{3} \mathrm{H} \leftrightarrow \mathrm{CH}_{2}(\mathrm{OH}) \mathrm{SO}_{3}{ }^{-}+\mathrm{H}^{+}
\end{gathered}
$$

Although the HMS formation mechanism has been proposed in many researches, there is no theoretical calculation on it. Thus, in order to confirm whether the mechanism is reliable, theoretical calculation is necessary to be done.

In this paper, we investigated the reaction $\mathrm{HCHO}$ with $\mathrm{HSO}_{3}{ }^{-}$and $\mathrm{SO}_{3}{ }^{2-}$ using quantum chemical calculations. In 
order to understand the influence of different aldehydes for the reactions, we also discussed the reaction between $\mathrm{CH}_{3} \mathrm{CHO}$ and $\mathrm{HSO}_{3}{ }^{-}$or $\mathrm{SO}_{3}{ }^{2-}$. Besides, the total rate constant $\left(k_{\text {total }}, \mathrm{M}^{-1} \mathrm{~s}^{-1}\right)$ for the individual reaction pathway within the range of 200 to $298 \mathrm{~K}$ were calculated. The further oxidation of the reaction products $\left(\mathrm{CH}_{2}(\mathrm{OH}) \mathrm{SO}_{3}{ }^{-}\right.$and $\left.\mathrm{CH}_{3} \mathrm{CH}_{2}(\mathrm{OH}) \mathrm{SO}_{3}{ }^{-}\right)$by $\mathrm{OH}$ radical and $\mathrm{O}_{2}$ also be talked about.

\section{Computational methods}

The Gaussian-09 suite of programs was used to perform all the quantum chemistry calculations described in this paper. The density functional theory (DFT) was used for calculations. ${ }^{18}$ All the geometrical structures (including reactants, pre-reactive complexes, transition states and products) calculated in this paper were optimized using the M06-2X functional at the 6$311++\mathrm{G}(\mathrm{d}, \mathrm{p})$ basis set. ${ }^{19,20}$ Vibrational frequencies were calculated at the same level of theory to ascertain the local minimum points and the transition states, which supposed to have zero and one imaginary frequency. We also performed intrinsic reaction coordinate (IRC) ${ }^{21}$ calculations in order to prove whether the transition state we found were the correct. Singlepoint energies were refined using the $\operatorname{CCSD}(T)$ method $^{22}$ with the aug-cc-pVTZ basis set. ${ }^{23-25}$ Very recently, many high level quantum chemical methods have been used for the atmosphere reactions in order to obtain more reliable and excellent intrinsic accuracy. ${ }^{26-28}$ In this article, under the consider of computational speed and accuracy, we think the dual-level strategy (CCSD(T)/aug-cc-pVTZ//M06-2X/6-311++G(d, p) level of theory) is appropriate. M06-2X functional has been widely used in theoretical calculation and can be better for ionic hydrogen-bonding interactions and identifying the global minimum conformer. $^{29-36}$ Been considered as the "gold standard" of quantum chemistry, $\operatorname{CCSD}(T)$ method was widely been used for reactions of organic matters and has high level accuracy. Thus we choose M06-2X functional at the $6-311++G(d, p)$ basis set for geometrical structures optimization and $\operatorname{CCSD}(T)$ method with the aug-cc-pVTZ basis set for single point energy calculation in this paper. ${ }^{22,37-40}$ The Gibbs free energies were calculated by the following equation: $G=E$ (single-point energy) $+G_{\text {corr }}$ (thermal correction to Gibbs free energy). The geometries were drawn using the CYLview software package. ${ }^{41}$

For the kinetics analysis, the conventional transition-state theory (TST) ${ }^{42}$ with Wigner tunneling correction was used to calculate the rate constants. All rate constants were calculated by using the KiSThelP program. ${ }^{43}$

\section{Results and discussion}

\section{Reaction of $\mathrm{HCHO}$ with dissolved $\mathrm{SO}_{2}$}

It aqueous phase, dissolved $\mathrm{SO}_{2}$ can be dissociated to form $\mathrm{HSO}_{3}{ }^{-}$and $\mathrm{SO}_{3}{ }^{2-}$. Thus, we focus on the reactions of $\mathrm{HSO}_{3}{ }^{-}+$ $\mathrm{HCHO}$ and $\mathrm{SO}_{3}{ }^{2-}+\mathrm{HCHO}$.

As shown in Fig. 1(a), when $\mathrm{HCHO}$ approaches $\mathrm{HSO}_{3}{ }^{-}$, the reaction occurs via a five-membered cyclic prereactive complex $\mathrm{HCHO}{ }^{-} \mathrm{HSO}_{3}{ }^{-}$(C1). $\mathrm{C} 1$ is regarded as the initial step of the $\mathrm{HCHO}$ and $\mathrm{HSO}_{3}{ }^{-}$reaction because $\mathrm{C} 1$ is connected with the transition state TS1. The C1 is held together through a hydrogen bond and an electron donor-acceptor type of interaction between the two molecules. The change of the distances of $\mathrm{C}_{\mathrm{b}} \cdots$ $\mathrm{O}_{\mathrm{d}}$ and $\mathrm{S}_{\mathrm{c}} \cdots \mathrm{Ce}$ are all shorten from $2.11 \AA$ (C1) to $1.70 \AA$ (TS1) and $3.24 \AA$ (C1) to $2.11 \AA$ (TS1), respectively. The reaction proceeds via a transition state TS1 with a barrier of $9.7 \mathrm{kcal} \mathrm{mol}^{-1}$ to produce $\mathrm{CH}_{2}(\mathrm{OH}) \mathrm{SO}_{3}{ }^{-}$(HMS).

When $\mathrm{SO}_{3}{ }^{2-}$ reacts with $\mathrm{HCHO}$, the process is similar with the $\mathrm{HCHO}+\mathrm{HSO}_{3}{ }^{-}$reaction. From Fig. 1(b), it can be found that the free energy of the complex $\mathrm{C} 2$ is $22.5 \mathrm{kcal} \mathrm{mol}^{-1}$ lower than reactants. Similar with $\mathrm{C} 1, \mathrm{C} 2$ is regarded as the initial step of the $\mathrm{HCHO}$ and $\mathrm{SO}_{3}{ }^{2-}$ reaction. The complex $\mathrm{C} 2$ is held together by one van der Waals interaction. The change of distance between $\mathrm{S}_{\mathrm{a}} \cdots \mathrm{C}_{\mathrm{b}}$ is from $2.91 \AA$ to $2.67 \AA$. The result is contrary to that of the $\mathrm{HCHO}+\mathrm{HSO}_{3}{ }^{-}$, in which the higher free energy of the $\mathrm{C} 1 \mathrm{can}$ be observed. Once the $\mathrm{C} 2$ is formed, it can easily transform to product $\mathrm{CH}_{2}\left(\mathrm{O}^{-}\right) \mathrm{SO}_{3}{ }^{-}$because the free energy of transition state TS2 is only $1.6 \mathrm{kcal} \mathrm{mol}^{-1}$ higher than the complex $\mathrm{C} 2$.

According to the analysis above, it is clear that the $\mathrm{SO}_{3}{ }^{2-}$ is more likely to react with $\mathrm{HCHO}$. However, the dissolved $\mathrm{SO}_{2}$ exist in the form of $\mathrm{HSO}_{3}{ }^{-}$in the $\mathrm{pH}$ range of $2-7,{ }^{44}$ and the acidic condition of aerosol particles can be found in Beijing winter haze. ${ }^{45}$ Thus, the $\mathrm{HSO}_{3}{ }^{-}$predominates in aerosol particles of Beijing winter haze so as to that the main reaction is $\mathrm{HCHO}+\mathrm{HSO}_{3}{ }^{-}$in these aerosol particles. And only the further oxidation of HMS will be discussed in the latter part.

\section{Reaction of $\mathrm{CH}_{3} \mathrm{CHO}$ with dissolved $\mathrm{SO}_{2}$}

In order to study the effect of different aldehydes on the reaction, we also discussed the reaction between $\mathrm{CH}_{3} \mathrm{CHO}$ with dissolved $\mathrm{SO}_{2}$. As shown in Fig. 2(a), $\mathrm{CH}_{3} \mathrm{CHO}+\mathrm{HSO}_{3}{ }^{-}$reaction is firstly considered. The reaction is initiated with the formation of a fiveringlike structure complex $\mathrm{CH}_{3} \mathrm{CHO} \cdots \mathrm{HSO}_{3}{ }^{-}$(C3), followed by the formation of a transition state TS3 to produce $\mathrm{CH}_{3} \mathrm{CH}(\mathrm{OH})$ $\mathrm{SO}_{3}{ }^{-}$(HES). The complex $\mathrm{C} 3$ is held together by one hydrogen bond and one van der Waals interaction. As shown in Fig. 2(a), the hydrogen atom $\left(\mathrm{H}_{\mathrm{b}}\right)$ of $\mathrm{HSO}_{3}{ }^{-}$interacts with the oxygen atom $\left(\mathrm{O}_{\mathrm{d}}\right)$ of $\mathrm{CH}_{3} \mathrm{CHO}$ to form one hydrogen bond, and the sulfur atom $\left(\mathrm{S}_{\mathrm{c}}\right)$ of $\mathrm{HSO}_{3}{ }^{-}$reacts with the carbon atom $\left(\mathrm{C}_{\mathrm{e}}\right)$ of $\mathrm{CH}_{3} \mathrm{CHO}$. It is obviously that the distances between $\mathrm{S}_{\mathrm{c}} \cdots \mathrm{C}_{\mathrm{e}}$ and $\mathrm{H}_{\mathrm{b}} \cdots \mathrm{O}_{\mathrm{d}}$ are all shorten. The barrier in this reaction is $16.6 \mathrm{kcal} \mathrm{mol}^{-1}$, which is larger than that of $\mathrm{HCHO}+\mathrm{HSO}_{3}{ }^{-}$reaction.

For $\mathrm{CH}_{3} \mathrm{CHO}+\mathrm{SO}_{3}{ }^{2-}$ reaction in Fig. 2(b), the formed complex $\mathrm{C} 4$ is also lower in energy than the reactants, which is similar with the $\mathrm{HCHO}+\mathrm{SO}_{3}{ }^{2-}$ reaction. The product $\mathrm{CH}_{3}$ $\mathrm{CH}\left(\mathrm{O}^{-}\right) \mathrm{SO}_{3}{ }^{-}$can be produced from the $\mathrm{C} 4$. The complex $\mathrm{C} 4$ is held together by one van der Waals interaction. As shown in Fig. 2(b), and sulfur atom $\left(\mathrm{S}_{\mathrm{a}}\right)$ is involved in the formation of van der Waals interaction with a carbon atom $\left(\mathrm{C}_{\mathrm{b}}\right)$ of $\mathrm{HSO}_{3}{ }^{-}$. The distance between $\mathrm{S}_{\mathrm{a}}$ and $\mathrm{C}_{\mathrm{b}}$ changes from $3.30 \AA$ (C4) to $2.49 \AA$ (TS4). The process needs to cross a transition state TS4 and to overcome the barrier of $2.5 \mathrm{kcal} \mathrm{mol}^{-1}$, which is higher than that in $\mathrm{HCHO}+\mathrm{SO}_{3}{ }^{2-}$ reaction.

On the basis of the results, it can be concluded that the reactivity of $\mathrm{HCHO}$ with dissolved $\mathrm{SO}_{2}$ is higher than that of another aldehydes with dissolved $\mathrm{SO}_{2}$. 
(a) $\mathrm{HCHO} \mathrm{HSO}_{3}^{-}$

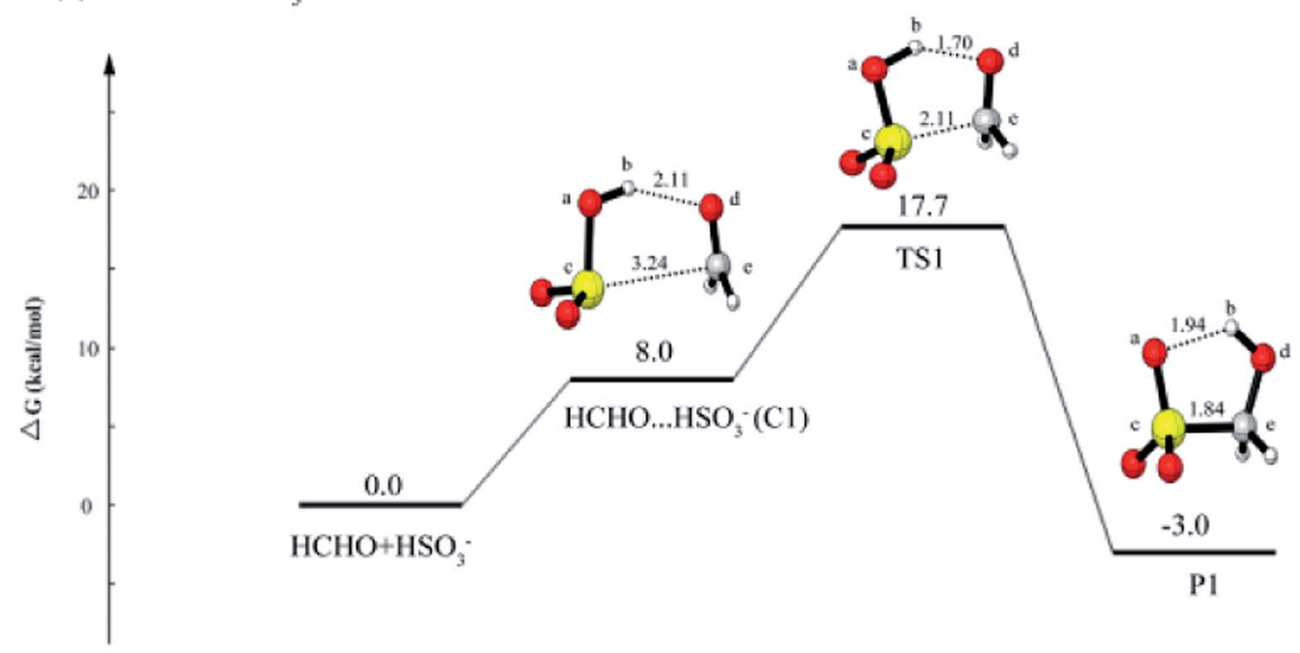

(b) $\mathrm{HCHO}+\mathrm{SO}_{3}^{2-}$

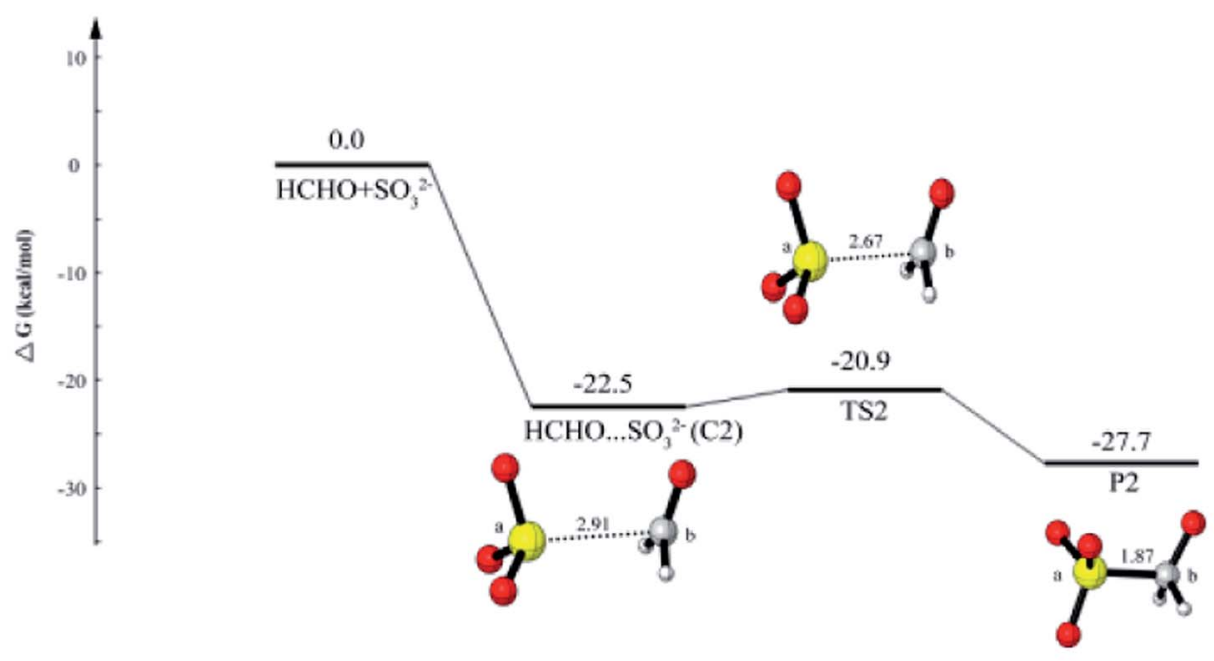

Fig. 1 The calculated free energy diagram for (a) the $\mathrm{HCHO}+\mathrm{HSO}_{3}{ }^{-}$reaction, and for (b) the $\mathrm{HCHO}+\mathrm{SO}_{3}{ }^{2-}$ reaction calculated at the $\mathrm{CCSD}(\mathrm{T}) /$ aug-cc-pVTZ//M06-2X/6-311++G(d, p) level of theory.

\section{Rate calculation}

In terms of the theoretical results discussed above, the reactions occur through a two-step mechanism, involving firstly a fast preequilibrium between the reactants and a pre-reactive complex, and the irreversible formation of the products, which can be characterized by eqn (7) and (8).

$$
\text { Step 1: } R \underset{k_{-1}}{\stackrel{k_{1}}{\longrightarrow}} \text { pre-reactive complex }
$$

Step 2: pre-reactive complex $\stackrel{k_{2}}{\rightarrow}$ products

In the above reactions, $k_{1}$ is the kinetic rate constant characterizing the forward bimolecular reaction step (in $\mathrm{cm}^{3}$ per molecule per s), whereas $k_{-1}$ and $k_{2}$ represent the backward and forward unimolecular reaction rate constants (in $\mathrm{s}^{-1}$ ). A steadystate analysis of the total reaction pathway's rate constant is formulated as:

$$
k_{\mathrm{total}}=\frac{k_{1} k_{2}}{k_{-1}+k_{2}}=k_{\mathrm{eq}} k_{2}
$$

And $K_{\text {eq }}$ and $k_{2}$ are the equilibrium constant of the first step and the rate constant of the second step in the reactions, respectively. The computed data are shown in Table 1.

The rate constants of $\mathrm{HCHO}+\mathrm{SO}_{3}{ }^{2-}$ are $\sim 10^{9}$ to $10^{7}$ times

than that of $\mathrm{HCHO}+\mathrm{HSO}_{3}{ }^{-}$, whereas rate constants of $\mathrm{CH}_{3} \mathrm{CHO}$ $+\mathrm{SO}_{3}{ }^{2-}$ is 8-6 orders of magnitude larger than that of $\mathrm{CH}_{3} \mathrm{CHO}$ $+\mathrm{HSO}_{3}{ }^{-}$within range of 200-298 $\mathrm{K}$. These results show that the reaction between aldehydes and $\mathrm{SO}_{3}{ }^{2-}$ is faster, which is consistent with the analysis above. For $\mathrm{HCHO}$ and $\mathrm{CH}_{3} \mathrm{CHO}$, it 


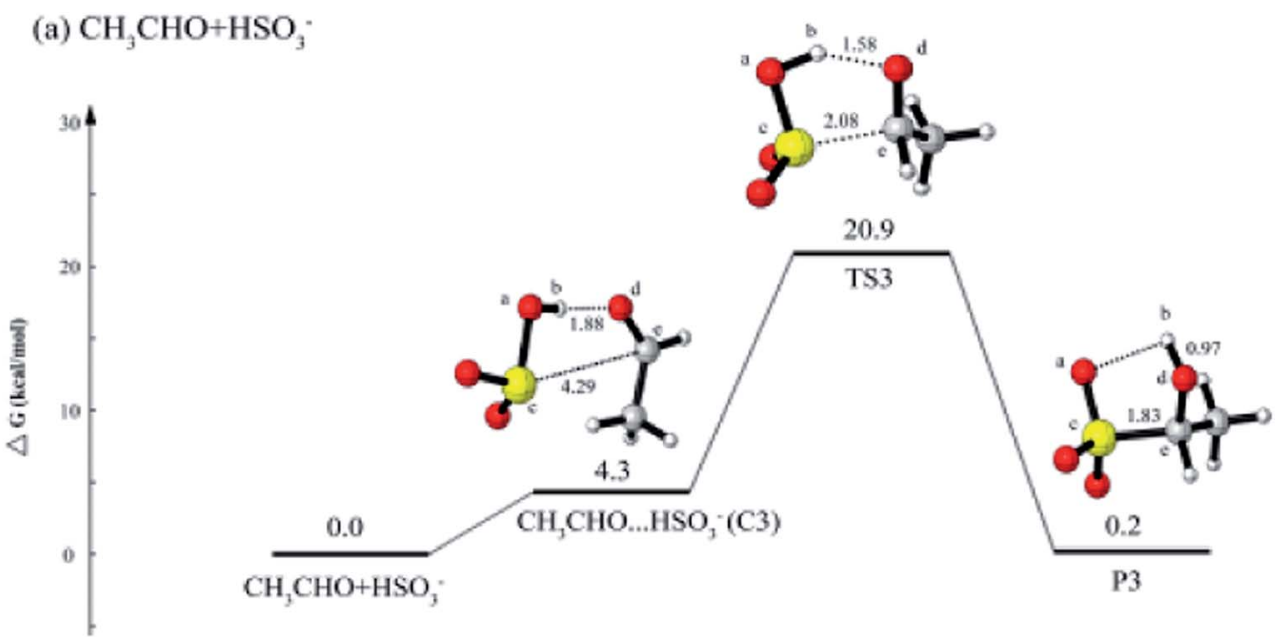

\section{(b) $\mathrm{CH}_{3} \mathrm{CHO}+\mathrm{SO}_{3}^{2+}$}
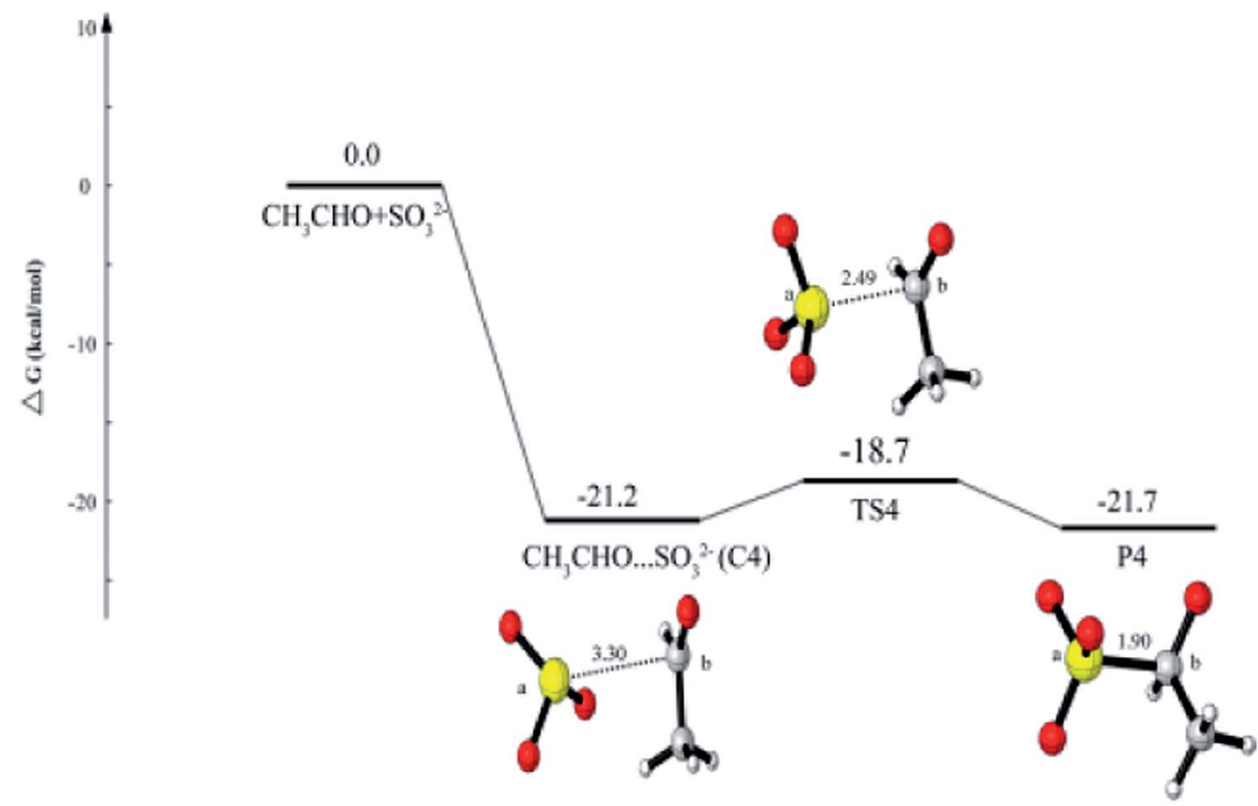

Fig. 2 The calculated free energy diagram for (a) the $\mathrm{CH}_{3} \mathrm{CHO}+\mathrm{HSO}_{3}{ }^{-}$reaction, and for (b) the $\mathrm{CH}_{3} \mathrm{CHO}+\mathrm{SO}_{3}{ }^{2-}$ reaction calculated at the $\operatorname{CCSD}(T) /$ aug-cc-pVTZ//M06-2X/6-311++G(d, p) level of theory.

is clear that the rate constants between $\mathrm{HCHO}$ and $\mathrm{HSO}_{3}{ }^{-}$or $\mathrm{SO}_{3}{ }^{2-}$ are larger than that between $\mathrm{CH}_{3} \mathrm{CHO}$ and $\mathrm{HSO}_{3}{ }^{-}$or $\mathrm{SO}_{3}{ }^{2-}$, which is coincident with the discussion above.
Although the reaction between aldehydes and $\mathrm{SO}_{3}{ }^{2-}$ is faster, $\mathrm{HSO}_{3}{ }^{-}$is the main form of dissolved $\mathrm{SO}_{2}$ in the aerosol particles, leading to that the reaction of aldehydes with $\mathrm{HSO}_{3}{ }^{-}$

Table 1 The total rate constant $\left(k_{\text {total }}, \mathrm{M}^{-1} \mathrm{~s}^{-1}\right)$ for the individual reaction pathway within the temperature range from 200 to $298 \mathrm{~K}$

\begin{tabular}{|c|c|c|c|c|c|c|}
\hline $\mathrm{HCHO}+\mathrm{HSO}_{3}{ }^{-} \rightarrow \mathrm{CH}_{2}(\mathrm{OH}) \mathrm{SO}_{3}{ }^{-}$ & $4.00 \times 10^{-3}$ & $1.70 \times 10^{-2}$ & $6.06 \times 10^{-2}$ & $1.73 \times 10^{-1}$ & $4.27 \times 10^{-1}$ & $8.60 \times 10^{-1}$ \\
\hline $\mathrm{HCHO}+\mathrm{SO}_{3}{ }^{2-} \rightarrow \mathrm{CH}_{2}\left(\mathrm{O}^{-}\right) \mathrm{SO}_{3}{ }^{-}$ & $3.21 \times 10^{6}$ & $2.74 \times 10^{6}$ & $2.42 \times 10^{6}$ & $2.20 \times 10^{6}$ & $2.04 \times 10^{6}$ & $1.93 \times 10^{6}$ \\
\hline $\mathrm{CH}_{3} \mathrm{CHO}+\mathrm{SO}_{3}{ }^{2-} \rightarrow \mathrm{CH}_{3} \mathrm{CH}\left(\mathrm{O}^{-}\right) \mathrm{SO}_{3}{ }^{-}$ & $3.96 \times 10^{2}$ & $5.85 \times 10^{2}$ & $8.23 \times 10^{2}$ & $1.10 \times 10^{3}$ & $1.43 \times 10^{3}$ & $1.76 \times 10^{3}$ \\
\hline
\end{tabular}


predominates in the aqueous phase of aerosol particles. Thus, in the next part, only $\mathrm{CH}_{2}(\mathrm{OH}) \mathrm{SO}_{3}{ }^{-}$and $\mathrm{CH}_{3} \mathrm{CH}(\mathrm{OH}) \mathrm{SO}_{3}{ }^{-}$will be talked about.

\section{Oxidation of HMS and HES}

As the oxidation of HMS is of great importance, it is meaningful and necessary to investigate the oxidation mechanism. Previous research ${ }^{46}$ has investigated the oxidation of HMS with $\mathrm{H}_{2} \mathrm{O}_{2}$ and $\mathrm{O}_{3}$, there was no calculation on the oxidation by $\mathrm{OH}$ radical. Thus, we will calculate the $\mathrm{HMS}+\mathrm{OH}$ reaction so as to confirm whether peroxysulfate radicals $\left(\mathrm{SO}_{5}{ }^{-}\right)$can be produced.

Fig. 3(a) shows the potential energy profile for $\mathrm{CH}_{2}(\mathrm{OH}) \mathrm{SO}_{3}{ }^{-}$ $+\mathrm{OH}$ reaction. In the reaction process, HMS firstly reacts with
$\mathrm{OH}$ radical to form the complex $\mathrm{CH}_{2}(\mathrm{OH}) \mathrm{SO}_{3}{ }^{-} \cdots \mathrm{OH}(\mathrm{C} 5)$ with the free energy release of $35.2 \mathrm{kcal} \mathrm{mol}^{-1}$. The $\mathrm{C} 5$ can evolve via TS5 with a barrier of $29.9 \mathrm{kcal} \mathrm{mol}^{-1}$ into $\mathrm{CH}_{2}(\mathrm{OH})_{2}$ and $\mathrm{SO}_{3}{ }^{\cdot-}$. The $\mathrm{SO}_{3}{ }^{-}{ }^{-}$can continue to react with $\mathrm{O}_{2}$ to produce $\mathrm{SO}_{5}{ }^{\cdot-}$. The addition reaction between $\mathrm{SO}_{3}{ }^{-}$and $\mathrm{O}_{2}$ can occur via a transition state TS6 with the barrier of $12.2 \mathrm{kcal} \mathrm{mol}^{-1}$.

The further oxidation mechanism of $\mathrm{CH}_{3} \mathrm{CH}(\mathrm{OH}) \mathrm{SO}_{3}{ }^{-}$(HES) by $\mathrm{OH}$ radical is similar with that of $\mathrm{HMS}$ by $\mathrm{OH}$ radical. As can be seen from Fig. 3(b), OH radical is added to HES to produce the complex $\mathrm{CH}_{3} \mathrm{CH}(\mathrm{OH}) \mathrm{SO}_{3}{ }^{-} \cdots \mathrm{OH}$ (C6). The reaction proceeds via a transition state TS7 with a barrier of $31.0 \mathrm{kcal} \mathrm{mol}{ }^{-1}$. The formed $\mathrm{SO}_{3}{ }^{-}$in this reaction also react with $\mathrm{O}_{2}$ to form $\mathrm{SO}_{5}{ }^{\circ-}$, and the process has the same barrier of $12.2 \mathrm{kcal} \mathrm{mol}{ }^{-1}$.

(a) $\mathrm{CH}_{2}(\mathrm{OH}) \mathrm{SO}_{3}+\cdot \cdot \mathrm{OH}$

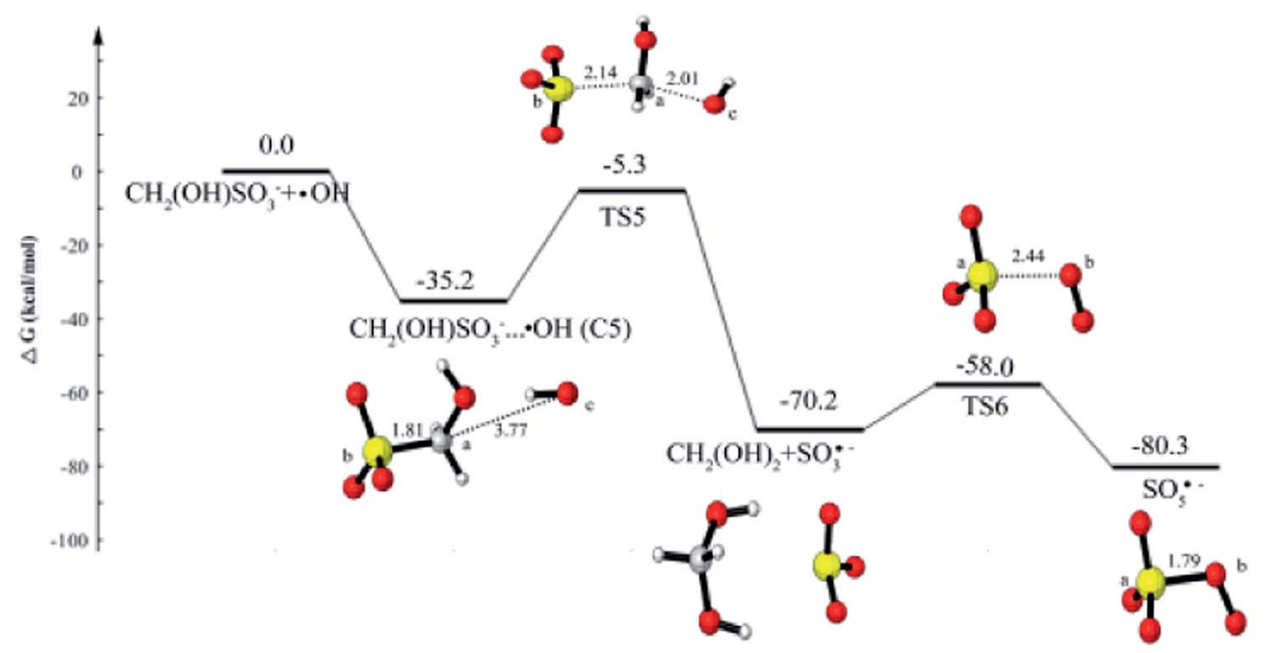

(b) $\mathrm{CH}_{3} \mathrm{CH}(\mathrm{OH}) \mathrm{SO}_{3}+\cdot \cdot \mathrm{OH}$

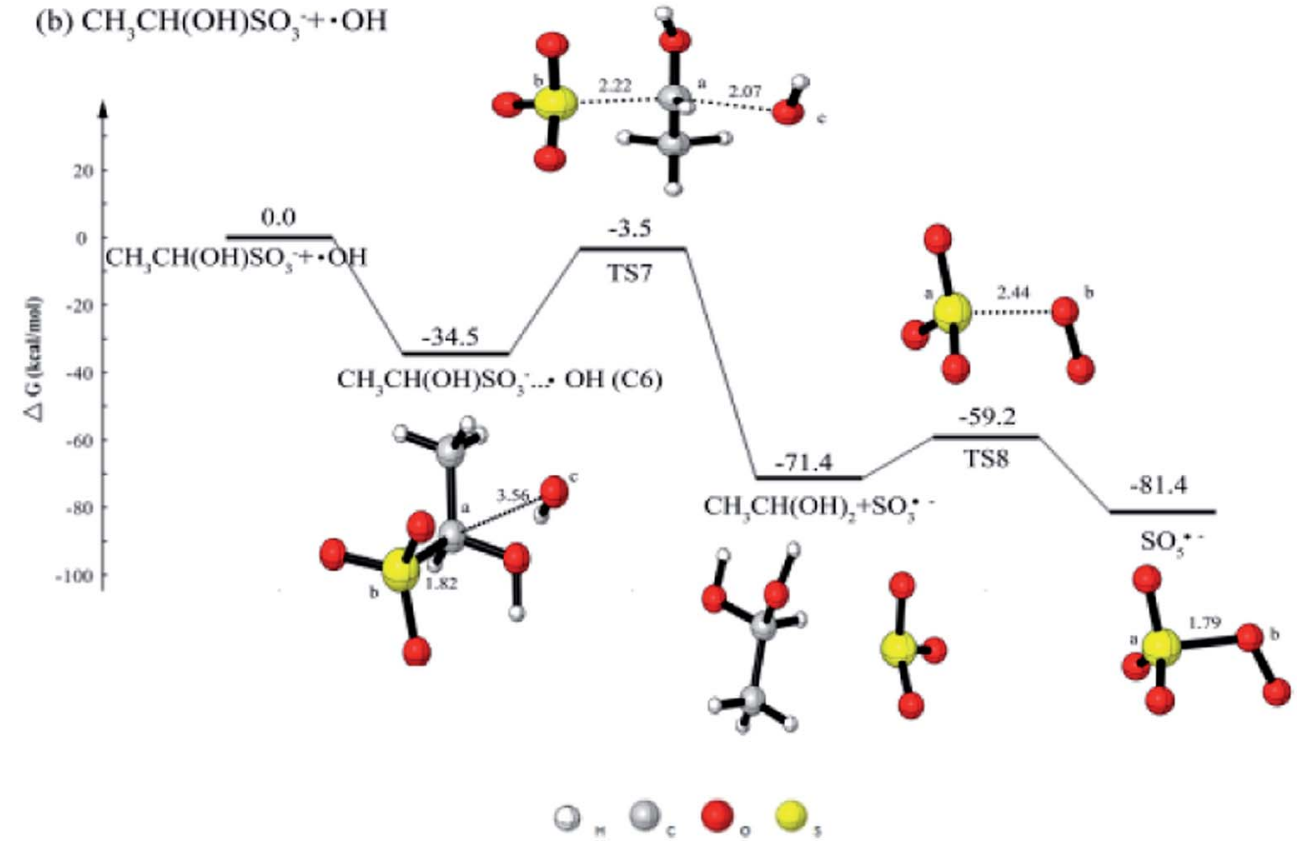

Fig. 3 The calculated free energy diagram for (a) the $\mathrm{CH}_{2}(\mathrm{OH}) \mathrm{SO}_{3}{ }^{-}+\cdot \mathrm{OH}$ reaction, and for (b) the $\mathrm{CH}_{3} \mathrm{CH}(\mathrm{OH}) \mathrm{SO}_{3}{ }^{-}+\cdot \mathrm{OH}$ reaction calculated at the $\operatorname{CCSD}(\mathrm{T}) /$ aug-cc-pVTZ//M06-2X/6-311++G(d, p) level of theory. 


\section{Conclusions}

HMS is the major OS species. In this paper, we investigated the formation of HMS using the quantum chemical calculations. Besides, other aldehydes like acetaldehyde also exist in the atmosphere. The similar structure between formaldehyde and acetaldehyde makes us to think the effect of different aldehydes on their reaction with dissolved $\mathrm{SO}_{2}$. Thus, the reaction between acetaldehyde and dissolved $\mathrm{SO}_{2}$ also was discussed.

The result shows that the energy barrier for $\mathrm{CH}_{3} \mathrm{CHO}+$ $\mathrm{HSO}_{3}{ }^{-}$reaction is $16.6 \mathrm{kcal} \mathrm{mol}^{-1}$, which is a little higher than $9.7 \mathrm{kcal} \mathrm{mol}^{-1}$ for reaction of $\mathrm{HCHO}$ with $\mathrm{HSO}_{3}{ }^{-}$. The barrier $\left(2.5 \mathrm{kcal} \mathrm{mol}^{-1}\right)$ of $\mathrm{CH}_{3} \mathrm{CHO}+\mathrm{SO}_{3}{ }^{2-}$ reaction is larger than that $\left(1.6 \mathrm{kcal} \mathrm{mol}^{-1}\right.$ ) of $\mathrm{HCHO}$ and $\mathrm{SO}_{3}{ }^{2-}$ reaction. These results indicate that the reaction of aldehydes with $\mathrm{SO}_{3}{ }^{2-}$ is easier than that with $\mathrm{HSO}_{3}{ }^{-}$. However, the $\mathrm{HSO}_{3}{ }^{-}$is the main form of dissolved $\mathrm{SO}_{2}$ in the aerosol particles, leading to that the aldehydes $+\mathrm{HSO}_{3}{ }^{-}$reaction dominates. Thus, the main products are $\mathrm{CH}_{2}(\mathrm{OH}) \mathrm{SO}_{3}{ }^{-}$and $\mathrm{CH}_{3} \mathrm{CH}(\mathrm{OH}) \mathrm{SO}_{3}{ }^{-}$. Their further oxidation by $\mathrm{OH}$ radical and $\mathrm{O}_{2}$ shows that the $\mathrm{SO}_{3}{ }^{--}$and $\mathrm{SO}_{5}{ }^{--}$ radical can be formed.

\section{Conflicts of interest}

There are no conflicts to declare.

\section{Acknowledgements}

This work is supported by National Natural Science Foundation of China (21607011), Natural Science Foundation of Shandong Province (ZR2018MB043), The Fundamental Research Funds of Shandong University (2018JC027) and Focus on Research and Development Plan in Shandong Province (2019GSF109037).

\section{Notes and references}

1 D. J. Eatough and L. D. Hansen, Sci. Total Environ., 1984, 36, 319-328.

2 R. W. Dixon and H. Aasen, Atmos. Environ., 1999, 33, 20232029.

3 J. D. Surratt, J. H. Kroll, T. E. Kleindienst, E. O. Edney, M. Claeys, A. Sorooshian, N. L. Ng, J. H. Offenberg, M. Lewandowski, M. Jaoui, R. C. Flagan and J. H. Seinfeld, Environ. Sci. Technol., 2007, 41, 517-527.

4 Y. Iinuma, C. Müller, T. Berndt, O. Böge, M. Claeys and H. Herrmann, Environ. Sci. Technol., 2007, 41, 6678-6683.

5 J. D. Blando, R. J. Porcja, T.-H. Li, D. Bowman, P. J. Lioy and B. J. Turpin, Environ. Sci. Technol., 1998, 32, 604-613.

6 M. P. Tolocka and B. Turpin, Environ. Sci. Technol., 2012, 46, 7978-7983.

7 R. J. Charlson, J. E. Lovelock, M. O. Andreae and S. G. Warren, Nature, 1987, 326, 655-661.

8 M. Claeys, W. Wang, R. Vermeylen, I. Kourtchev, X. Chi, Y. Farhat, J. D. Surratt, Y. Gómez-González, J. Sciare and W. Maenhaut, J. Aerosol Sci., 2010, 41, 13-22.

9 J. Liao, K. D. Froyd, D. M. Murphy, F. N. Keutsch, G. Yu, P. O. Wennberg, J. M. St. Clair, J. D. Crounse, A. Wisthaler,
T. Mikoviny, J. L. Jimenez, P. Campuzano-Jost, D. A. Day, W. Hu, T. B. Ryerson, I. B. Pollack, J. Peischl, B. E. Anderson, L. D. Ziemba, D. R. Blake, S. Meinardi and G. Diskin, J. Geophys. Res.: Atmos., 2015, 120, 2990-3005.

10 D. D. Huang, Y. J. Li, B. P. Lee and C. K. Chan, Environ. Sci. Technol., 2015, 49, 3672-3679.

11 T. M. Olson and M. R. Hoffmann, Atmos. Environ., 1989, 23, 985-997.

12 S. Song, M. Gao, W. Xu, Y. Sun, D. R. Worsnop, J. T. Jayne, Y. Zhang, L. Zhu, M. Li, Z. Zhou, C. Cheng, Y. Lv, Y. Wang, W. Peng, X. Xu, N. Lin, Y. Wang, S. Wang, J. W. Munger, D. J. Jacob and M. B. McElroy, Atmos. Chem. Phys., 2019, 19, 1357-1371.

13 C. Wagner, Ber. Dtsch. Chem. Ges., 1929, 62, 2873-2877.

$14 \mathrm{P}$. Jones and K. Oldham, The theory of the formaldehyde clock reaction, 1963.

15 P. Bell Ronald and P. G. Evans, Proc. R. Soc. London, Ser. A, 1966, 291, 297-323.

16 S. D. Boyce and M. R. Hoffmann, J. Phys. Chem., 1984, 88, 4740-4746.

17 J. W. Munger, D. J. Jacob, J. M. Waldman and M. R. Hoffmann, J. Geophys. Res., 1983, 88, 5109-5121.

18 L. Vereecken and J. S. Francisco, Chem. Soc. Rev., 2012, 41, 6259-6293.

19 Y. Zhao and D. G. Truhlar, Theor. Chem. Acc., 2008, 120, 215241.

20 R. Krishnan, J. S. Binkley, R. Seeger and J. A. Pople, J. Chem. Phys., 1980, 72, 650-654.

21 K. Fukui, in Frontier Orbitals and Reaction Paths, World Scientific, 1997, vol. 7, pp. 471-476.

22 G. D. Purvis and R. J. Bartlett, J. Chem. Phys., 1982, 76, 19101918.

23 A. K. Wilson, T. van Mourik and T. H. Dunning, J. Mol. Struct.: THEOCHEM, 1996, 388, 339-349.

24 J. A. Pople, M. Head-Gordon and K. Raghavachari, J. Chem. Phys., 1987, 87, 5968-5975.

25 A. Godfrey-Kittle and M. Cafiero, Int. J. Quantum Chem., 2006, 106, 2035-2043.

26 B. Long, J. L. Bao and D. G. Truhlar, J. Am. Chem. Soc., 2016, 138, 14409-14422.

27 B. Long, J. L. Bao and D. G. Truhlar, Proc. Natl. Acad. Sci. U. S. A., 2018, 115, 6135-6140.

28 B. Long, J. L. Bao and D. G. Truhlar, J. Am. Chem. Soc., 2019, 141, 611-617.

29 M. Walker, A. J. A. Harvey, A. Sen and C. E. H. Dessent, J. Phys. Chem. A, 2013, 117, 12590-12600.

30 D. S. Huh and S. J. Choe, J. Porphyrins Phthalocyanines, 2010, 14, 592-604.

31 H. A. Rypkema, A. Sinha and J. S. Francisco, J. Phys. Chem. A, 2015, 119, 4581-4588.

32 B. Long, X.-F. Tan, C.-R. Chang, W.-X. Zhao, Z.-W. Long, D.-S. Ren and W.-J. Zhang, J. Phys. Chem. A, 2013, 117, 5106-5116.

33 S. Pari, I. A. Wang, H. Liu and B. M. Wong, Environ. Sci.: Processes Impacts, 2017, 19, 395-404.

34 X. Shi, R. Zhang, Y. Sun, F. Xu, Q. Zhang and W. Wang, Phys. Chem. Chem. Phys., 2018, 20, 1005-1011. 
35 N. Rashidian, E. Zahedi and A. Shiroudi, Sci. Total Environ., 2019, 679, 106-114.

36 A. S. M. Gad El-Hak, A. A. K. Mohammed, A. F. Abdel Hakiem and R. M. Mahfouz, Spectrochim. Acta, Part A, 2019, 222, 117200.

37 G. Knizia, T. B. Adler and H.-J. Werner, J. Chem. Phys., 2009, 130, 054104.

38 P. R. Nagy, G. Samu and M. Kállay, J. Chem. Theory Comput., 2018, 14, 4193-4215.

39 M. B. Oviedo, N. V. Ilawe and B. M. Wong, J. Chem. Theory Comput., 2016, 12, 3593-3602.

40 J. Řezáč and P. Hobza, Chem. Rev., 2016, 116, 5038-5071.

41 C. Y. Legault, CYLview 1.0 b, Université de Sherbrooke, 2009, http://www.cylview.org.
42 D. G. Truhlar, B. C. Garrett and S. J. Klippenstein, J. Phys. Chem., 1996, 100, 12771-12800.

43 S. Canneaux, F. Bohr and E. Henon, J. Comput. Chem., 2014, 35, 82-93.

44 R. Zhang, G. Wang, S. Guo, M. L. Zamora, Q. Ying, Y. Lin, W. Wang, M. Hu and Y. Wang, Chem. Rev., 2015, 115, 3803-3855.

45 S. Song, M. Gao, W. Xu, J. Shao, G. Shi, S. Wang, Y. Wang, Y. Sun and M. B. McElroy, Atmos. Chem. Phys., 2018, 18, 7423-7438.

46 J. W. Munger, C. Tiller and M. R. Hoffmann, Science, 1986, 231, 247. 